\title{
Pomegranate Polyphenols Downregulate Expression of Androgen Synthesizing Genes in Human Prostate Cancer Cells Overexpressing the Androgen Receptor
}

\author{
Mee Young Hong ${ }^{*}$, , Navindra P. Seeram, and David Heber \\ Center For Human Nutrition, David Geffen School of Medicine, University of California, Los Angeles, \\ 90095, USA
}

\begin{abstract}
Prostate cancer is dependent on circulating testosterone in its early stages and is treatable with radiation and surgery. However, recurrent prostate tumors advance to an androgen-independent state where they progress in the absence of circulating testosterone leading to metastasis and death. During the development of androgen independence, prostate cancer cells are known to increase intracellular testosterone synthesis which maintains cancer cell growth in the absence of significant amounts of circulating testosterone. Overexpression of the androgen receptor (AR) occurs in androgenindependent prostate cancer and has been proposed as another mechanism promoting the development of androgen independence. The LNCaP-AR cell line is engineered to overexpress AR but is otherwise similar to the widely studied LNCaP cell line. We have previously shown that pomegranate extracts inhibit both androgen-dependent and androgen-independent prostate cancer cell growth. In the present study, we examined the effects of pomegranate polyphenols, ellagitanninrich extract and whole juice extract on the expression of genes for key androgen synthesizing enzymes and the AR. We measured expression of the HSD3B2, AKR1C3 and SRD5A1 genes for the respective androgen synthesizing enzymes in $\mathrm{LNCaP}, \mathrm{LNCaP}-\mathrm{AR}$, and DU-145 human prostate cancer cells. A two-fold suppression of gene expression was considered statistically significant. Pomegranate polyphenols inhibited gene expression and AR most consistently in the LNCaP-AR cell line $(P=.05)$. Therefore, inhibition by pomegranate polyphenols of gene expression involved in androgen synthesis enzymes and the AR may be of particular importance in androgen-independent prostate cancer cells and the subset of human prostate cancers where AR is upregulated.
\end{abstract}

\section{Keywords}

pomegranate; punicalagin; ellagic acid; prostate cancer; androgen receptor; androgen-independence

\section{Introduction}

Pomegranate (Punica granatum L.) fruits are globally consumed in fresh, in processed forms as juice, jam, wine and oil, and in extract supplements [1]. They contain high levels of a diverse range of phytochemicals of which polyphenols including punicalagin (PA), ellagic acid (EA),

†Corresponding author. Tel.: (310) 206-1987; Fax: (310) 206-5264. E-mail address: myhong @ mednet.ucla.edu.

*Current address: School of Exercise and Nutritional Sciences, San Diego State University, San Diego, 92182, USA

Publisher's Disclaimer: This is a PDF file of an unedited manuscript that has been accepted for publication. As a service to our customers we are providing this early version of the manuscript. The manuscript will undergo copyediting, typesetting, and review of the resulting proof before it is published in its final citable form. Please note that during the production process errors may be discovered which could affect the content, and all legal disclaimers that apply to the journal pertain. 
gallotannins, anthocyanins (cyanidin, delphinidin and pelargonidin glycosides), and other flavonoids (quercetin, kaempferol and luteolin glycosides) [1-6]. PA is the most abundant of these polyphenols and EA has been previously shown to exhibit anticarcinogenic properties such as induction of cell-cycle arrest and apoptosis, as well as the inhibition of tumor formation and growth in animals [7-9]. Pomegranate juice (PJ) consumption also has shown potent anticarcinogenic properties in various cancers [4,10-15].

Adenocarcinoma of the prostate is currently the most common malignancy in men in the United States, comprising $32 \%$ of all cancers and prostate cancer remains the second most common cause of cancer death in men in the United States, accounting for $11 \%$ of all cancer deaths (16). Both androgen and androgen receptor (AR) are recognized risk factors in the development of prostate cancer [17-20]. These observations are further corroborated by genetic evidence from transgenic mouse models, suggesting that increased AR signaling in the prostate is linked to an increase in precancerous lesions [21]. Since elevated level of androgen causes enhancement of prostate cancer, reduction of circulating levels of androgens is central to the treatment of prostate cancer $[22,23]$. The most effective treatment for early-stage prostate cancer includes suppression of AR function either by blocking androgen signaling with the anti-androgens bicalutamide (Casodex) or flutamide or by inhibiting the conversion of testosterone to the potent androgen dihydrotestosterone (DHT) with finasteride [22]. However, 30\% of these patients show relapse of the disease within 3 years as a result of the emergence of androgenindependent prostate cancer cells, which are either AR positive or AR negative [24,25]. Therefore, novel approaches are needed to treat advanced prostate cancer. AR can be activated despite androgen blockade therapy in AR-positive prostate cancer [26] via an increased sensitivity of AR to low concentrations of androgen.

Epidemiological studies suggest that the risk of prostate cancer is reduced by consumption of a phytochemical-rich diet of fruits and vegetables [27]. Because pomegranates are widely consumed and have recently been shown to affect prostate cancer, the effects of pomegranate polyphenols (PA and EA) and pomegranate extract (POMx) and pomegranate juice (PJ) on cell proliferation and apoptosis were examined in androgen-dependent (LNCaP) and independent human prostate cancer cell lines (LNCaP-AR and DU-145). Since androgen and AR play central roles throughout prostate cancer development, the effects of pomegranate polyphenols on the transcription of genes for androgen synthesizing enzymes (HSD3B2, AKR1C3 and SRD5A1) and for AR were evaluated.

\section{Materials and methods}

\subsection{Cell culture materials}

The LNCaP and DU-145 prostate cancer cell lines were obtained from American Type Culture Collection (ATCC, Manassas, VA). LNCaP-AR (a generous gift from Dr. C. Sawyers at UCLA) cell line was developed at UCLA, derived from LNCaP cell (ATCC) [21]. LNCaP, LNCaP-AR and DU-145 prostate cancer cells were grown in RPMI 1640 media and the media contained $10 \%$ fetal bovine serum (FBS) (Life Technologies, Grand Island, NY) in the presence of $100 \mathrm{U} / \mathrm{ml}$ penicillin and $0.1 \mathrm{~g} / \mathrm{L}$ streptomycin (Life Technologies). Cells were incubated at $37^{\circ} \mathrm{C}$ with $95 \%$ air and $5 \% \mathrm{CO}_{2}$. All cells were maintained below passage 20 and used in experiments during the linear phase of growth.

\subsection{Confirmation of androgen dependence and independence}

FBS treatment experiment-Cells were seeded into 96-well plates a density of 10,000 cells/well for $24 \mathrm{~h}$ in 10\% FBS-RPMI1640 media, and then treated with phenol-free RPMI media (MP Biochemical, Irvine, CA) supplemented with $2 \%$ FBS, $2 \%$ charcoal-dextranstipped FBS (CS-FBS) (Invitrogen, Carlsbad, CA) or no FBS (serum free) for $72 \mathrm{hrs.} \mathrm{Then}$ 
cell proliferation was measured to test if $\mathrm{LNCaP}$ cells are androgen-dependent, LNCaP-AR and DU-145 cells are androgen-independent. According to the manufacturer's data sheet, CSFBS contains very low concentration of steroid hormones (estradiol, progesterone, cortisol and testosterone) compared to normal FBS. Serum-free (SF) media treated cells were used as negative controls.

Hormone treatment experiment-Cells were seeded into 96-well plates a density of 20,000 cells/well for $24 \mathrm{~h} \mathrm{10 \%} \mathrm{FBS-RPMI} 1640$ media and stabilized in $2 \%$ CS-FBS phenolfree RPMI media for another $24 \mathrm{~h}$. Then the cells were treated with $10 \mathrm{nM}$ DHT, $1 \mathrm{nM} \beta$ estradiol or $1 \mathrm{ng} / \mathrm{ml}$ IGF1 for $96 \mathrm{~h}$ to measure their effects on cell proliferation. The cells incubated with $2 \%$ CS-FBS were used as controls. All three hormones were purchased in Sigma Aldrich (St. Louis, MO) and dissolved in ethanol (ethanol concentration not exceeding $0.001 \%)$. Three replicates per condition were assayed and data averaged from 4-6 separate experiments are presented. Treatment media was refreshed every 24 or $48 \mathrm{~h}$ of treatment.

\subsection{Preparation of POMx, PJ, PA and EA}

POMx is a standardized extract (POM Wonderful Inc., Los Angeles, CA) of pomegranate fruit grown in California (Punica granatum L., Wonderful variety, Paramount Farms, Lost Hills, CA). POMx contains monomeric and oligomeric ellagitannins as PA (37-40\%) and 3.4\% free EA but no anthocyanins as determined by high performance liquid chromatography (HPLC) using previously described methods [28]. PJ (POM Wonderful Inc.) is commercially available for human consumption and was used in concentrate powder form of whole pomegranate juice. It contains $1 \mathrm{mg} / \mathrm{ml}$ punicalagin, $0.97 \mathrm{mg} / \mathrm{ml} \mathrm{EA}$ and anthocyanins [28]. Monomeric and oligomeric ellagitannins as PA were purified from fruit husk as previously reported and analyzed by HPLC and liquid chromatography electrospray ionization mass spectroscopy (LCESI/MS) (22). EA was purchased from Sigma Aldrich (St. Louis, MO).

\subsection{Cell proliferation assay}

Proliferation was measured using the CellTiter-Glo Luminescent Cell Viability Assay (Promega, Madison, WI). When added to cells, the assay reagent produces luminescence in the presence of ATP from viable cells. After seeding of cells for $24 \mathrm{~h}$, the cells were treated with PA, EA, POMx (normalized PA content) and PJ (normalized PA content) for $72 \mathrm{~h}$ at $3.125,6.25,12.5,25$ or $50 \mu \mathrm{g} / \mathrm{ml}$ concentrations. For hormone treated cells, PA, EA, POMx and PJ were tested at $12.5,25$ and $50 \mu \mathrm{g} / \mathrm{ml}$ concentrations. All stock solution of samples were solubilized in dimethy sulfoxide (DMSO) and final concentration of DMSO in media was $<0.1$ $\%$. At the end of treatment, plates were equilibrated at room temperature for $30 \mathrm{~min}, 100 \mu \mathrm{l}$ of the assay reagent was added to each well and cell lysis was induced on an orbital shaker for 2 $\mathrm{min}$. Plates were incubated at room temperature for $10 \mathrm{~min}$ to stabilize the luminescence signal and results were read on an Orion Microplate Luminometer (Bertholds Detection Systems, Pforzheim, Germany). All plates had control wells containing medium without cells to obtain a value for background luminescence. Data are expressed as proportion of untreated cells and at least three independent experiments were replicated.

\subsection{Apoptosis assay}

Apoptosis was assessed using the Cell Death Detection ELISA ${ }^{\text {PLUS }}$ Assay (Roche, Indianapolis, IN). This assay is a photometric enzyme-linked immunoassay (ELISA) that quantitatively measures the internucleosomal degradation of DNA, which occurs during apoptosis. Specifically, the assay detects histone-associated mono-and oligonucleosomes, which are indicators of apoptosis. Cells were plated in 60-mm dishes at a density of 100,000 cells/dish and allowed to attach for $24 \mathrm{~h}$. Cells were treated with vehicle control ( $0.1 \%$ final concentration of DMSO), PA, EA, POMx $(50 \mu \mathrm{g} / \mathrm{ml})$ or PJ $(100 \mu \mathrm{g} / \mathrm{ml})$ for $48 \mathrm{~h}$. Following 
treatments, nonadherent cells were collected and pelleted at $200 \times \mathrm{g}$. Adherent cells were washed with PBS (Invitrogen, Carlsbad, CA), trypsinized, collected and combined with nonadherent cells into a total of $1 \mathrm{ml}$ medium. Both live and dead cells were than counted via trypan blue exclusion (Pierce, Rockford, IL), and equal number of cells were added to the microtiter plate for all treatment groups, and apoptosis assay was performed according to the manufacturer's instructions. Data are expressed as percentage of control absorbance at $405 \mathrm{~nm}$ of each sample over vehicle controls and at least three independent experiments were replicated.

\subsection{RNA extraction and reverse transcription}

Total RNA was extracted using RNeasy Mini Kit (Qiagen, Valencia, CA). Sample RNA content was quantified by measuring the absorbance at $260 \mathrm{~nm}$ with a Gene Quant Spectrophotometer (Amersham-Pharmacia Biotech, Piscataway, NJ). Reverse transcription was performed on $3 \mu \mathrm{g}$ of RNA by using oligo $(\mathrm{dT})_{12-18}$ primers (Invitrogen) with SuperScript III Reverse Transcriptase (Invitrogen) according to the manufacturer's instruction.

\subsection{Quantitative real time PCR}

Gene expression of $3 \beta$-hydroxysteroid dehydrogenase type 2 (HSD3B2), aldo-keto reductase family 1, typeC3 (AKR1C3), steroid $5 \alpha$ reductase type 1 (SRD5A1) and androgen receptor (AR) were determined using Taqman Universal PCR master mix and primers (Applied Biosystems, Foster City, CA) by real time polymerase chain reaction (PCR) using the ABI 7900 HT Sequence Detector (Applied Biosystems). The transcription level of target genes was normalized to $18 \mathrm{~S}$ expression. The expression levels of $\mathrm{r} 18 \mathrm{~S}$ were similar among samples. Every other sample had the RT reaction repeated on a separate occasion, followed by PCR and quantitation to confirm the reproducibility of the assay. In addition, every set of RT reactions contains a minus RT negative control to confirm that no contamination or anomaly has occurred.

\subsection{Statistics}

Data were analyzed by Student's t test or one-way ANOVA followed by Student-NewmanKeuls (SNK) test with GraphPad PRISM 3.0 (GraphPad Software, San Diego, CA).

\section{Results}

The androgen dependence of the LNCaP prostate cancer cell line and the androgenindependence of LNCaP-AR and DU-145 cell lines were confirmed by incubation of cells with FBS or charcoal-stripped serum without androgen (CS-FBS), and then by treatment with DHT, $\beta$-estradiol and IGF-1. CS-FBS and SF treatments decreased cell growth by more than $60 \%$ in LNCaP cells $(P<.001)$ (Fig. 1A). In contrast, the growth of LNCaP-AR and DU-145 cells with CS-FBS treatment was similar to that of the FBS treated cells (Fig. 1B and 1C). SF media incubation as a negative control inhibited the growth of LNCaP-AR and DU-145 cells $(P<$. 001) (Fig. 1B and 1C). Tumor cell growth with treatment of DHT, $\beta$-estradiol or IGF1 was induced by 2.7-, 2.4- and 1.5- fold, respectively in LNCaP cells $(P<.05)$ but the growth of LNCaP-AR and DU-145 cells was not affected (data not shown).

PA, EA, POMx and PJ treatments inhibited cell proliferation in a dose-dependent manner in androgen-dependent LNCaP and androgen-independent LNCaP-AR and DU-145 human prostate cancer cell lines $(P<.001)$ (Fig. 2$)$. In the $\mathrm{LNCaP}$ cell line all pomegranate polyphenols inhibited cell proliferation even in the presence of DHT, $\beta$-estradiol or IGF-1 (Fig.3). The antiproliferative effect of PJ and POMx (normalized to PA content) was much stronger than that of same amount of PA under all hormone treatment conditions (Fig. 2 and Fig. 3). The anti-proliferative effect of $\mathrm{PJ}$ was greater than that of POMx with normalization to PA content. 
The apoptotic effects of PJ and POMx and their purified polyphenols (PA and EA) on the LNCaP, LNCaP-AR and DU-145 prostate cancer cell lines were evaluated to ascertain whether the observed reductions in viable cell number were due to the induction of apoptosis. PA, EA and POMx (all at $50 \mu \mathrm{g} / \mathrm{ml}$ concentrations), and PJ $(100 \mu \mathrm{g} / \mathrm{ml}$ concentration) induced apoptosis in LNCaP cells by 2.5-, 3.3-, 1.7- and 3.2-fold, respectively $(P<.05)$ (Fig. 4A). In LNCaP-AR cells, PA, EA, POMx and PJ induced apoptosis by 1.8- 1.9-, 1.7- and 1.8-fold, respectively $(P<.05)$ (Fig. 4B), and in DU-145 cells by 1.9-, 3.3-, 1.9- and 1.7-fold, respectively $(P<.05)$ (Fig. 4C).

The effects of PA, EA and POMx (all at $50 \mu \mathrm{g} / \mathrm{ml}$ concentrations), and PJ (100 $\mu \mathrm{g} / \mathrm{ml}$ concentration) on the expression of androgen synthesizing enzymes and AR were examined in LNCaP, LNCaP-AR and DU-145 prostate cancer cells. Interestingly, HSD3B2 was expressed in LNCaP-AR in the greatest amounts, and to some extent in LNCaP cells. However, there was very little expression of HSD3B2 in DU-145 $(P<.01)$ (Table 1). While AKR1C3 was highly expressed in DU-145, it was expressed at very low levels in LNCaP and LNCaPAR cells $(P<.01)$ (Table 1). SRD5A1 expression was the greater in LNCaP-AR cells compared to LNCaP or DU-145 cells $(P<.01)$ (Table 1). Finally, AR expression was upregulated in LNCaP-AR cells compared to LNCaP cells $(P<.01)$ (Table 1), but DU-145 cells expressed the AR gene to a very small degree (Table 1$)$.

POMx reduced expression of HSD3B 2 by 4 fold in LNCaP cells compared to control $(P<.05)$ (Table 2). In LNCaP-AR cells, PA, EA, POMx and PJ downregulated the gene expression more than two fold compared to control $(P<.05)$ (Table 2). EA decreased AKR1C3 gene expression by two fold in DU-145 cells $(P<.05)$ (Table 2). POMx suppressed transcriptional level of SRD5A1 by more than 2 fold in LNCaP, LNCaP-AR and DU-145 cells $(P<.05)$ (Table 2). Androgen receptor (AR) expression was also reduced by POMx treatment by more than 3 fold in $\mathrm{LNCaP}$ cells $(P<.05)$, and by PA, POMx or PJ treatment by 2 fold in LNCaP-AR cells $(P<.05)$ (Table 2).

\section{Discussion}

Pomegranate fruits, juices, and extracts have been used extensively in ancient cultures for various medicinal purposes [29]. Pomegranate polyphenols are potent antioxidants which have been shown both in vitro and in vivo to inhibit the growth of prostate and some other forms of cancer [10-15]. Our group has demonstrated that 8 ounces of pomegranate juice consumed daily following primary treatment of prostate cancer significantly prolonged prostate specific antigen (PSA) doubling time from 15 months to 54 months [30]. We have also shown that pomegranate ellagitannins suppress prostate tumor formation in a SCID mouse xenograft model [31].

Androgens are critical to the normal development, proliferation, and differentiation of prostate epithelial cells and signaling occurs via intracellular AR [23,32]. Recurrent prostate cancer after primary treatment is typically androgen-dependent, and so androgen deprivation therapy is effective in causing a remission of prostate cancer. However, later in the course of the disease, with the development of androgen-independence AR expression is increased. Increased AR expression has been demonstrated both in animals with xenografts following castration and in about a third of human prostate cancers implicating AR in the development of androgenindependent prostate cancer [22,23]. Furthermore, in androgen-independent cancer cells testosterone is produced intracellularly by well-described enzymes to maintain tumor growth in the absence of significant circulating concentrations of testosterone [22,26]. These tumors are more difficult to treat therefore they arise with an eventual fatal outcome (23-26,33-35). For this reason, the prevention of the development of androgen-independent prostate cancer is a critical target for the reduction of prostate cancer mortality. In the current study, we tested 
the hypothesis that pomegranate polyphenols can inhibit the development of androgenindependent prostate cancer growth via inhibition of the expression of genes involved in androgen synthesis and the AR in human prostate cancer cell lines.

There are several enzymes which are involved in intracellular testosterone synthesis in the prostate cancer cell $(25,36-39)$. HSD3B2 catalyzes the conversion of dehydroepi-androsterone (DHEA) to androstenedione [25,36]. In addition, AKR1C3 converts androstenedione to testosterone and increased amounts of AKR1C3 have been demonstrated in prostatic adenocarcinoma and carcinoma [37]. Testosterone is converted to DHT by $5 \alpha$-reductase (SRD5A1) [38]. Since DHT has a higher affinity for AR than testosterone, it has been proposed that DHT is critical to prostate cancer development [36]. Inhibitors of SRD5A1 such as finasteride reduce prostate size, and have been shown to reduce the development of prostate cancers by 25 percent but to increase the numbers of advanced cancers found [40,41].

We measured gene expression of androgen-synthesizing enzymes in all three cell lines. It has previously been shown that mRNA levels of the enzymes are correlated with protein amounts and activities in other studies [46-50] so we did not repeat these studies.

In examining the effects of PJ and POMx on the various cell lines and taking a twofold suppression of gene expression as significant, it is clear that the most consistent suppression of both androgen-synthesizing enzymes and AR was seen in the LNCaP-AR cell line. There are other means by which prostate cancer cells can develop androgen-independence including the bypass of pathways that involve other growth signals. However, overexpression of AR is considered a significant pathway and these results suggest that pomegranate polyphenols may be particularly helpful in the subgroup of patients with androgen-independent prostate cancer and AR upregulation. Clinical studies to test this hypothesis are needed to confirm the importance of this observation.

Our current study showed that pomegranate protects against prostate cancer by downregulation of genes involved in androgen synthesis. However, the mechanism of the downregulation is not known. One study [51] implicated the involvement of the cAMP-protein kinase signal transduction pathway in regulating lymphocyte expression of HSD17B1. Therefore, cAMPprotein kinase signal transduction pathway may be one of the mechanisms for downregulation of androgen synthesizing enzymes. However, our data are premature to establish the hypothesis, and this remains further study.

In the present study, we confirmed observations by other laboratories [42-45] demonstrating that LNCaP cells are androgen-dependent, and LNCaP-AR and DU-145 cells are androgenindependent. LNCaP-AR cells are engineered to overexpress AR, which models a mechanism of androgen independence seen in about one-third of androgen-independent prostate cancers clinically. It is likely that the mechanisms underlying androgen-independent growth are different in LNCaP-AR cells compared to DU-145 cells. LNCaP-AR cells are androgenindependent by overexpressing AR while DU-145 cells are androgen-independent with low levels of AR expression.

The current study showed that pomegranate products and their polyphenols reduced tumor cell growth and induced apoptosis in both androgen-dependent and -independent prostate cancer cells. These anti-proliferative effects were also consistent in hormone-treated cells. This implies the potential possibility that pomegranate and its polyphenols are used as novel dietary supplements with maximum potential for androgen-dependent and -independent prostate chemoprevention. By the way, more studies are needed to determine how the alteration of cell proliferation and apoptosis is related to the expression of androgen synthesizing enzymes and AR. 
It was observed that there were differences in the apoptosis between cell lines and test compounds. For example, the POMx was relatively not effective in all cell lines and the LNCaP-AR cells were more resistant than the other two cell lines. EA treatment showed higher apoptosis response in LNCaP and DU-145 than LNCaP-AR cells. Further studies are needed to explain the cell type-specific and test compound-specific responses on apoptosis.

In the current study, PJ at $100 \mu \mathrm{g} / \mathrm{ml}$ concentration compared to POMx, PA and EA at $50 \mu \mathrm{g} /$ $\mathrm{ml}$ was applied to measure its effect on apoptosis. Our preliminary data showed that PJ did not show the pro-apoptotic effect at concentration of $50 \mu \mathrm{g} / \mathrm{ml}$ but did show at $100 \mu \mathrm{g} / \mathrm{ml}$ concentration. This may occur because PJ is a diluted form compared to the POMx and the pure compounds.

The biological properties associated with pomegranate fruits prompted us to evaluate their major phytochemical ingredients both as extracts and as single purified compounds, PA and EA. We demonstrated that PJ and POMx were more potent inhibitor of cell growth than isolated individual polyphenols in all three cell lines suggesting synergistic and/or additive effects of several phytochemicals present in PJ and POMx including proanthocyanidins, anthocyanins (glycosides of delphinidin, peonidin and cyanidin) and flavonoid glycosides [1-6]. All of these have been shown to have antioxidant and antiproliferative activities [1,52]. These observations were also consistent with our previous studies of the effects of pomegranate polyphenols on the RWPE-1 and 22RV1 prostate cancer cell lines [53].

Our recent study [31] showed that EA was detected in serum $(134 \mathrm{ng} / \mathrm{ml})$ and prostate $(676$ $\mathrm{ng} / \mathrm{ml}$ ) after intraperitoneal administration of pomegranate extract in mouse. It is a significant observation that EA is more targeted to prostate tissue which implies the beneficial role of pomegranate against prostate cancer. The level of ellagic acid level in prostate tumor in vivo is not known. More data from in vitro and in vivo studies should be conducted to decide the application amount for clinical studies.

In short, $\mathrm{PJ}$ and POMx and their polyphenols showed a capability to arrest proliferation and stimulate apoptosis in human androgen-dependent and -independent prostate cancer cells. Inhibition of gene expression involved in androgen synthesis enzymes and the androgen receptor may contribute to growth inhibitory effects of pomegranate polyphenols and may provide a molecular target for the inhibition of the emergence of androgen-independent prostate cancer.

\section{Acknowledgements}

The authors thank POM Wonderful Inc. (Los Angeles, CA) for the generous provision of pomegranate extract and juice. The authors also thank Yanjun Zhang for the preparation of punicalagin power of pomegranate and Dr. Simin Liu for allowing us to use his real time PCR equipment. This study was funded by UCLA/NCI Clinical Nutrition Research Unit Grant No. CA 42710. This work was also funded by Dr. M. Y. Hong's W81XWH-07-1-0158 grant from Department of Defense.

Funding sources: This study was funded by UCLA/NCI Clinical Nutrition Research Unit Grant No. CA 42710 and grant number W81XWH-07-1-0158 (M.Y. Hong) from Department of Defense.

\section{References}

1. Gil MI, Tomas-Barberan FA, Hess-Pierce B, Holcroft DM, Kader AA. Antioxidant activity of pomegranate juice and its relationship with phenolic composition and processing. J Agric Food Chem 2000;48:4581-9. [PubMed: 11052704]

2. Aviram M, Dornfield L, Rosenblatt M, Volkova N, Kaplan M, Coleman R, Hayek T, Presser D, Fuhrman B. Pomegranate juice consumption reduces oxidative stress, atherogenic modifications to 
LDL, and platelet aggregation: studies in humans and in atherosclerotic apolipoprotein E-deficient mice. Am J Clin Nutr 2000;71:1062-76. [PubMed: 10799367]

3. Kaplan M, Hayek T, Raz A, Coleman R, Dornfield L, Vaya J, Aviram M. Pomegranate juice supplementation to atherosclerotic mice reduces macrophage lipid peroxidation, cellular cholesterol accumulation and development of atherosclerosis. J Nutr 2001;131:2082-9. [PubMed: 11481398]

4. Kim ND, Mehta R, Yu W, Neeman I, Livney T, Amichay A, Poirier D, Nicholls P, Kirby A, Jiang W, Mansel R, Ramachandran C, Rabi T, Kaplan B, Lansky E. Chemopreventive and adjuvant therapeutic potential of pomegranate (Punica granatum) for human breast cancer. Breast Cancer Res Treat 2002;71:203-17. [PubMed: 12002340]

5. Cerda B, Ceron JJ, Tomas-Barberan FA, Espin JC. Repeated oral administration of high doses of pomegranate ellagitannin punicalagin to rats for 37 days is not toxic. $\mathbf{J}$ Agric Food Chem 2003;51:3493-501. [PubMed: 12744688]

6. Cerda B, Llorach R, Ceron JJ, Espin JC, Tomas-Barberan FA. Evaluation of the bioavailability and metabolism in the rat of punicalagin, an antioxidant polyphenol from pomegranate juice. Eur $\mathrm{J}$ Nutr 2003;42:18-28. [PubMed: 12594538]

7. Narayanan BA, Geoffrey O, Willingham MC, Re GG, Nixon DW. p53/p21 (WAF1/CIP1) expression and its possible role in G1 arrest and apoptosis in ellagic acid treated cancer cells. Cancer Lett 1999;136:215-21. [PubMed: 10355751]

8. Khanduja KL, Gandhi RK, Pathania V, Syanl N. Prevention of $N$-nitrosodiethylamine-induced lung tumorigenesis by ellagic acid and quercetin in mice. Food Chem Toxicol 1999;137:313-8. [PubMed: 10418948]

9. Mertens-Talcott SU, Talcott ST, Percival SS. Low concentrations of quercetin and ellagic acid synergistically influence proliferation, cytotoxicity and apoptosis in MOLT-4 human leukemia cells. J Nutr 2003;133:2669-74. [PubMed: 12888656]

10. Adams LS, Seeram NP, Aggarwal BB, Takada Y, Sand D, Heber D. Pomegranate juice, total pomegranate ellagitannins, and punicalagin suppress inflammatory cell signaling in colon cancer cells. J Agric Food Chem 2006;54:980-5. [PubMed: 16448212]

11. Albrecht M, Jiang W, Kumi-Diaka J, Lansky EP, Gommersall LM, Mansel RE, Neeman I, Geldof AA, Campbell MJ. Pomegranate extracts potently suppress proliferation, xenograft growth, and invasion of human prostate cancer cells. J Med Food 2004;7:274-83. [PubMed: 15383219]

12. Kawaii S, Lansky EP. Differentiation-promoting activity of pomegranate (Punica granatum) fruit extracts in HL-60 human promyelocytic leukemia cells. J Med Food 2004;7:13-8. [PubMed: 15117547]

13. Toi M, Bando H, Ramachandran C, Melnick SJ, Imai A, Fife RS, Carr RE, Oikawa T, Lansky EP. Preliminary studies on the anti-angiogenic potential of pomegranate fractions in vitro and in vivo. Angiogenesis 2003;6:121-8. [PubMed: 14739618]

14. Hora JJ, Maydew ER, Lansky EP, Dwivedi C. Chemopreventive effects of pomegranate seed oil on skin tumor development in CD1 mice. J Med Food 2003;6:157-61. [PubMed: 14585180]

15. Kohno H, Suzuki R, Yasui Y, Hosokawa M, Miyashita K, Tanaka T. Pomegranate seed oil rich in conjugated linolenic acid suppresses chemically induced colon carcinogenesis in rats. Cancer Sci 2004;95:481-6. [PubMed: 15182427]

16. American Cancer Society Cancer facts and figures 2007. Atlanta, GA: 2007. www.cancer.org

17. Pienta KJ, Esper PS. Risk factors for prostate cancer. Ann Intern Med 1993;118:793-803. [PubMed: 8470854]

18. Denis LJ, Griffiths K. Endocrine treatment in prostate cancer. Semin Surg Oncol 2000;18:52-74. [PubMed: 10617897]

19. Thompson I, Feigl P, Coltman C. Chemoprevention of prostate cancer with finasteride. Important Adv Oncol 1995:57-76. [PubMed: 7672814]

20. Heinlein CA, Chang C. Androgen receptor in prostate cancer. Endocr Rev 2004;25:276-308. [PubMed: 15082523]

21. Stanbrough M, Leav I, Kwan PW, Bubley GJ, Balk SP. Prostatic intraepithelial neoplasia in mice expressing an androgen receptor transgene in prostate epithelium. Proc Natl Acad Sci U S A 2001;98:10823-8. [PubMed: 11535819] 
22. Attard G, Sarker D, Reid A, Molife R, Parker C, de Bono JS. Improving the outcome of patients with castration-resistant prostate cancer through rational drug development. Br J Cancer 2006;95:767-74. [PubMed: 16983403]

23. Chen CD, Welsbie DS, Tran C, Baek SH, Chen R, Vessella R, Rosenfeld MG, Sawyers CL. Molecular determinants of resistance to antiandrogen therapy. Nat Med 2004;10:33-9. [PubMed: 14702632]

24. Kokontis JM, Hay N, Liao S. Progression of LNCaP prostate tumor cells during androgen deprivation: hormone-independent growth, repression of proliferation by androgen, and role for p27Kip1 in androgen-induced cell cycle arrest. Mol Endocrinol 1998;12:941-53. [PubMed: 9658399]

25. Culig Z, Hoffmann J, Erdel M, Eder IE, Hobisch A, Hittmair A, Bartsch G, Utermann G, Schneider MR, Parczyk K, Klocker H. Switch from antagonist to agonist of the androgen receptor bicalutamide is associated with prostate tumour progression in a new model system. Br J Cancer 1999;81:242-51. [PubMed: 10496349]

26. Zhang L, Johnson M, Le KH, Sato M, Ilagan R, Iyer M, Gambhir SS, Wu L, Carey M. Interrogating androgen receptor function in recurrent prostate cancer. Cancer Res 2003;63:4552-60. [PubMed: 12907631]

27. Block G, Patterson B, Subar A. Fruit, vegetables and cancer prevention: a review of the epidemiological evidence. Nutr Cancer 1992;18:1-29. [PubMed: 1408943]

28. Seeram NP, Lee R, Hardy ML, Heber D. Large-scale purification of ellagitannins from pomegranate husk, a by-product of the commercial juice industry. Sep Purif Tech 2005;41:49-55.

29. Longtin R. The pomegranate: nature's power fruit? J Natl Cancer Inst 2003;95:346-8. [PubMed: 12618495]

30. Pantuck AJ, Leppert JT, Zomorodian N, Aronson W, Hong J, Barnard RJ, Seeram N, Liker H, Wang $\mathrm{H}$, Elashoff R, Heber D, Aviram M, Ignarro L, Belldegrun A. Phase II study of pomegranate juice for men with rising prostate-specific antigen following surgery or radiation for prostate cancer. Clin Cancer Res 2006;12:4018-26. [PubMed: 16818701]

31. Seeram NP, Aronson W, Zhang Y, Henning SM, Moro A, Lee R, Satippour M, Harris DM, Rettig M, Suchard MA, Pantuck AJ, Belldegrun A, Heber D. Pomegranate ellagitannin derived metabolites inhibits prostate cancer growth and localize to the mouse prostate gland. J Agric Food Chem 2007;55:7732-7. [PubMed: 17722872]

32. Jariwala U, Prescott J, Jia L, Barski A, Pregizer S, Cogan JP, Arasheben A, Tilley WD, Scher HI, Gerald WL, Buchanan G, Coetzee GA, Frenkel B. Identification of novel androgen receptor target genes in prostate cancer. Mol Cancer 2007;6:39. [PubMed: 17553165]

33. Kim D, Gregory CW, French FS, Smith GJ, Mohler JL. Androgen receptor expression and cellular proliferation during transition from androgen-dependent to recurrent growth after castration in the CWR22 prostate cancer xenograft. Am J Pathol 2002;160:219-26. [PubMed: 11786415]

34. Scher HI, Sawyers CL. Biology of progressive, castration-resistant prostate cancer: directed therapies targeting the androgen-receptor signaling axis. J Clin Oncol 2005;23:8253-61. [PubMed: 16278481]

35. Callewaert L, Van Tilborgh N, Claessens F. Interplay between two hormone-independent activation domains in the androgen receptor. Cancer Res 2006;66:543-53. [PubMed: 16397271]

36. Devgan SA, Henderson BE, Yu MC, Shi CY, Pike MC, Ross RK, Reichardt JK. Genetic variation of 3 beta-hydroxysteroid dehydrogenase type II in three racial/ethnic groups: implications for prostate cancer risk. Prostate 1997;33:9-12. [PubMed: 9294620]

37. Fung KM, Samara EN, Wong C, Metwalli A, Krlin R, Bane B, Liu CZ, Yang JT, Pitha JV, Culkin DJ, Kropp BP, Penning TM, Lin HK. Increased expression of type 2 3alpha-hydroxysteroid dehydrogenase/type 5 17beta-hydroxysteroid dehydrogenase (AKR1C3) and its relationship with androgen receptor in prostate carcinoma. Endocr Relat Cancer 2006;13:169-80. [PubMed: 16601286]

38. Torres JM, Ruiz E, Ortega E. Development of a quantitative RT-PCR method to study 5alphareductase mRNA isozymes in rat prostate in different androgen status. Prostate 2003;56:74-9. [PubMed: 12746849]

39. Stanbrough M, Bubley GJ, Ross K, Golub TR, Rubin MA, Penning TM, Febbo PG, Balk SP. Increased expression of genes converting adrenal androgens to testosterone in androgen-independent prostate cancer. Cancer Res 2006;66:2815-25. [PubMed: 16510604]

40. Steers WD. 5alpha-reductase activity in the prostate. Urology 2001;58:17-24. [PubMed: 11750244] 
41. Thompson IM, Goodman PJ, Tangen CM, Lucia MS, Miller GJ, Ford LG, Lieber MM, Cespedes RD, Atkins JN, Lippman SM, Carlin SM, Ryan A, Szczepanek CM, Crowley JJ, Coltman CA. The Influence of Finasteride on the Development of Prostate Cancer. N Engl J Med 2003;349:215-24. [PubMed: 12824459]

42. Arnold JT, Le H, McFann KK, Blackman MR. Comparative effects of DHEA vs. testosterone, dihydrotestosterone, and estradiol on proliferation and gene expression in human LNCaP prostate cancer cells. Am J Physiol Endocrinol Metab 2005;288:E573-84. [PubMed: 15536203]

43. King KJ, Nicholson HD, Assinder SJ. Effect of increasing ratio of estrogen: androgen on proliferation of normal human prostate stromal and epithelial cells, and the malignant cell line LNCaP. Prostate 2006;66:105-14. [PubMed: 16114065]

44. Lee SO, Lou W, Hou M, de Miguel F, Gerber L, Gao AC. Interleukin-6 promotes androgenindependent growth in LNCaP human prostate cancer cells. Clin Cancer Res 2003;9:370-6. [PubMed: 12538490]

45. Zhao XY, Ly LH, Peehl DM, Feldman D. 1alpha,25-dihydroxyvitamin D3 actions in LNCaP human prostate cancer cells are androgen-dependent. Endocrinology 1997;138:3290-8. [PubMed: 9231780]

46. Fung KM, Samara EN, Wong C, Metwalli A, Krlin R, Bane B, Liu CZ, Yang JT, Pitha JV, Culkin DJ, Kropp BP, Penning TM, Lin HK. Increased expression of type 2 3alpha-hydroxysteroid dehydrogenase/type 5 17beta-hydroxysteroid dehydrogenase (AKR1C3) and its relationship with androgen receptor in prostate carcinoma. Endocr Relat Cancer 2006;13:169-80. [PubMed: 16601286]

47. Agís-Balboa RC, Pinna G, Zhubi A, Maloku E, Veldic M, Costa E, Guidotti A. Characterization of brain neurons that express enzymes mediating neurosteroid biosynthesis. Proc Natl Acad Sci U S A 2006;103:14602-7. [PubMed: 16984997]

48. McCartin S, Russell AJ, Fisher RA, Wallace AM, Arnhold IJ, Mason JI, Varley J, Mendonca BB, Sutcliffe RG. Phenotypic variability and origins of mutations in the gene encoding 3betahydroxysteroid dehydrogenase type II. J Mol Endocrinol 2000;24:75-82. [PubMed: 10656999]

49. Bird IM, Pasquarette MM, Rainey WE, Mason JI. Differential control of 17 alpha-hydroxylase and 3 beta-hydroxysteroid dehydrogenase expression in human adrenocortical H295R cells. J Clin Endocrinol Metab 1996;81:2171-8. [PubMed: 8964847]

50. Steckelbroeck S, Jin Y, Gopishetty S, Oyesanmi B, Penning TM. Human Cytosolic $3 \alpha-$ Hydroxysteroid Dehydrogenases of the Aldo-keto Reductase Superfamily Display Significant 3 $\beta$ Hydroxysteroid Dehydrogenase Activity. J Biol Chem 2004;279:10784-95. [PubMed: 14672942]

51. Zhou Z, Speiser PW. Regulation of HSD17B1 and SRD5A1 in lymphocytes. Mol Genet Metab 1999;68:410-7. [PubMed: 10562469]

52. Malik A, Mukhtar H. Prostate cancer prevention through pomegranate fruit. Cell cycle 2006;5:3713. [PubMed: 16479165]

53. Seeram NP, Adams LS, Henning SM, Niu Y, Zhang Y, Nair MG, Heber D. In vitro antiproliferative, apoptotic and antioxidant activities of punicalagin, ellagic acid and a total pomegranate tannin extract are enhanced in combination with other polyphenols as found in pomegranate juice. J Nutr Biochem 2005;16:360-7. [PubMed: 15936648]

\section{Abbreviations}

\section{AKR1C3}

aldo-keto reductase family 1 , member C3

AR

androgen receptor

DHT

dihydrotestosterone

CS-FBS

charcoal-stripped fetal bovine serum 


\section{DMSO}

dimethy sulfoxide

EA

ellagic acid

ELISA

enzyme-linked immunosorbent assay

FBS

fetal bovine serum

HPLC

high performance liquid chromatograph

HSD3B2

33-hydroxysteroid dehydrogenase type 2

IGF-1

insulin growth factor-1

PCR

polymerase chain reaction

SF

serum-free

SRD5A1

steroid $5 \alpha$ reductase type 1

PA

punicalagin

PJ

pomegranate juice

POMx

pomegranate extract 
(A)

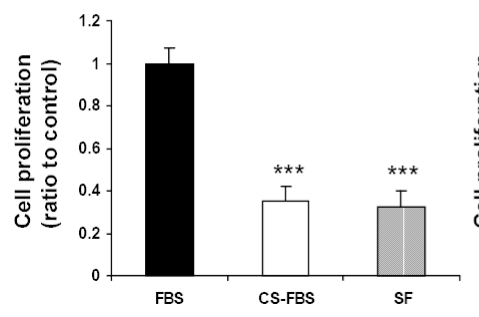

(B)

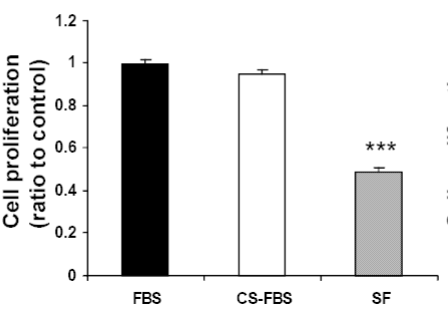

(C)

Fig. 1.

Effects of FBS, CS-FBS and SF on cell proliferation in $\operatorname{LNCaP}(\mathrm{A}), \mathrm{LNCaP}-\mathrm{AR}(\mathrm{B})$ and DU-145 (C) human prostate cancer cells. CS-FBS decreased cell proliferation in LNCaP but not in LNCaP-AR and DU-145 cells. As a negative control, SF treatment decreased cell proliferation in all cell lines. FBS: fetal bovine serum, CS-FBS: charcoal-stripped fetal bovine serum, SF: serum-free. Mean \pm SEM $(n=4-6)$. *** Significantly different from FBS at $P<$. 001. 
(A)

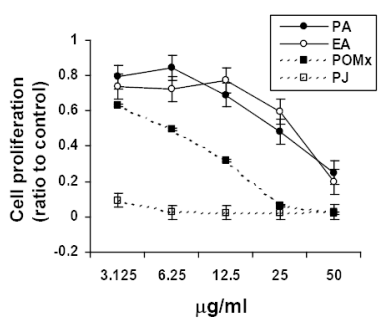

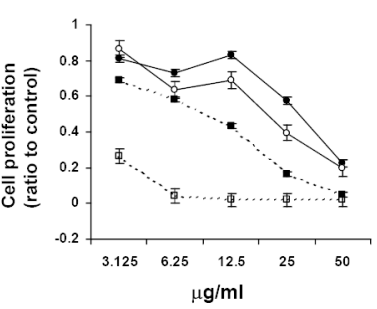

(C)

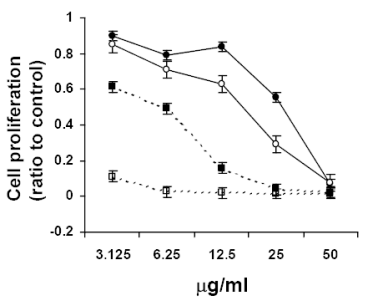

Fig. 2.

Antiproliferative effects of PA, EA, POMx and PJ in LNCaP (A), LNCaP-AR (B) and DU-145 (C) cells. Exposure to PA, EA, POMx or PJ for $72 \mathrm{~h}$ inhibited prostate cancer cell growth in a dose-dependent manner $(P<.01)$. PA: punicalagin, EA: ellagic acid, POMx: pomegranate extract, PJ: pomegranate juice. Mean $\pm \operatorname{SEM}(n=4-6)$. 
DHT

(A)

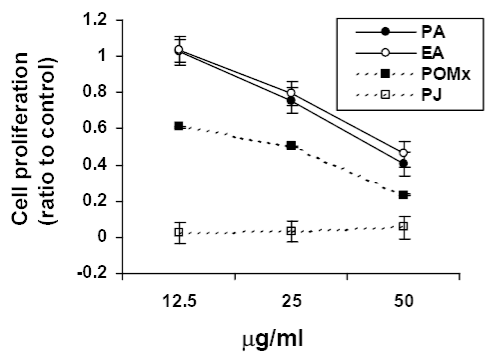

(B)

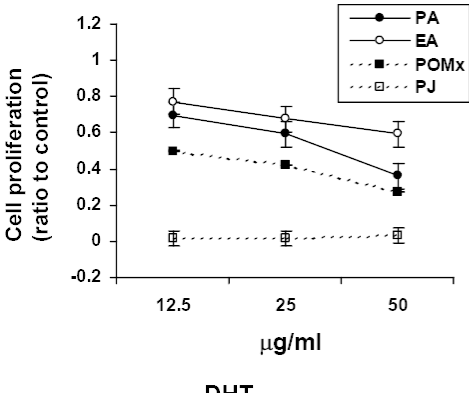

(C)

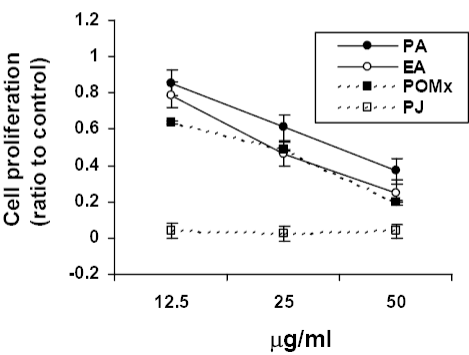

$\beta$-estradiol
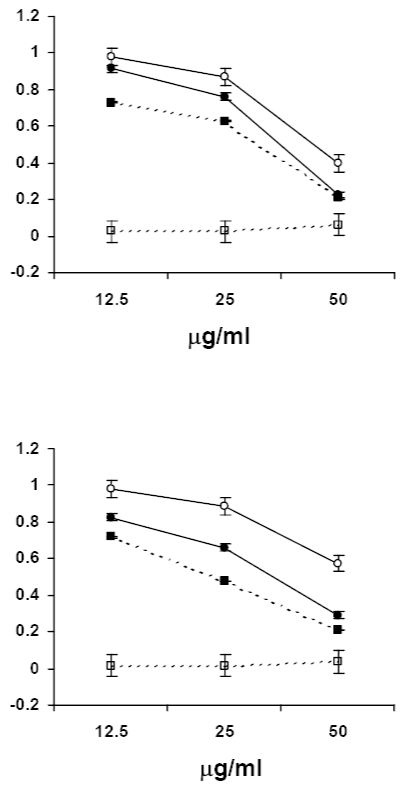

$\beta$-estradiol

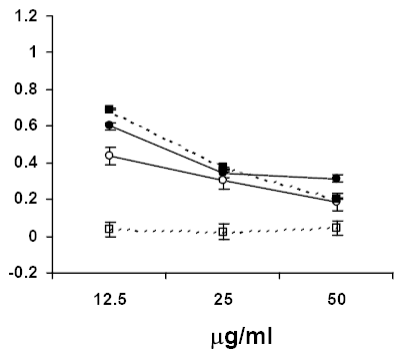

IGF-1
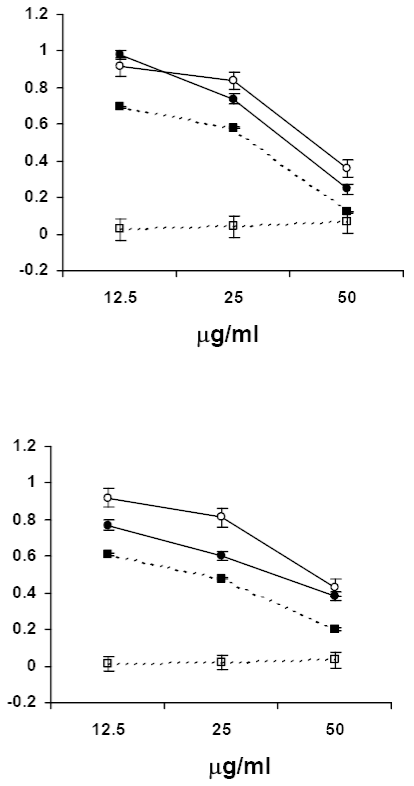

IGF-1

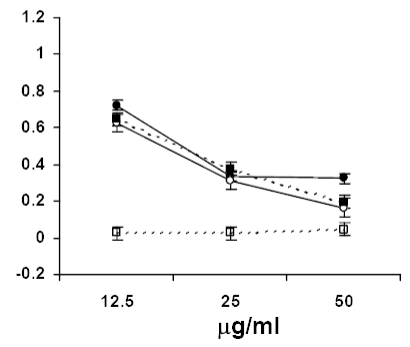

Fig. 3.

Antiproliferative effects of PA, EA, POMx and PJ in hormone (DHT, $\beta$-estradiol or IGF-1)treated LNCaP (A), LNCaP-AR (B) and DU-145 (C) cells. PA, EA, POMx or PJ inhibited hormone exposed prostate cancer cell growth in a dose-dependent manner $(P<.01)$. Mean \pm SEM ( $n=4-6)$. 
(A)

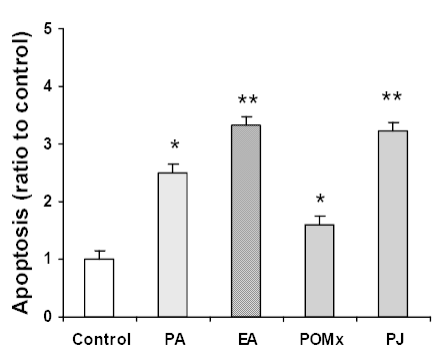

(B)

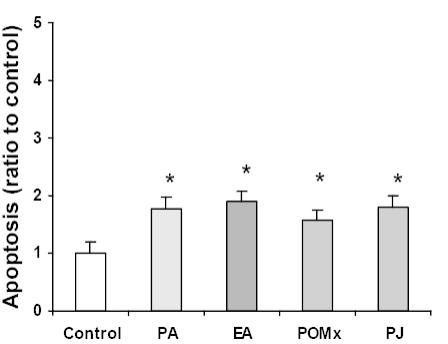

(C)

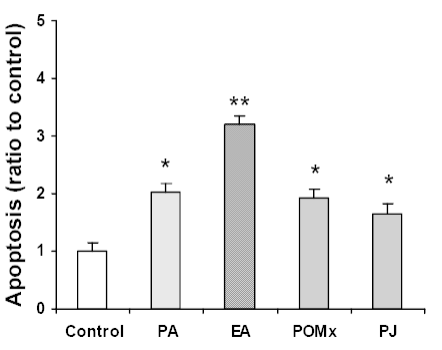

Fig. 4.

Proapoptotic effects of PA, EA, POMx and PJ in LNCaP (A), LNCaP-AR (B) and DU-145 (C) cells. Cells exposed to PA, EA, POMx or PJ for $48 \mathrm{~h}$ enhanced apoptosis. Cells were treated $50 \mu \mathrm{g} / \mathrm{ml}$ of PA, EA or POMx, or $100 \mu \mathrm{g} / \mathrm{ml}$ of PJ. Mean \pm SEM $(n=4-6)$. *, ** Significantly different from control at $P<.05$ or $P<.01$ respectively. 
Table 1

Differential expression of HSD3B2, AKR1C3 and SRD5A1 in LNCaP, LNCaP-AR and DU-145 prostate cancer cells \begin{tabular}{l|r|r|r|r|}
\hline Cell Line & HSD3B2 & AKR1C & SRD5A1 & AR \\
\hline
\end{tabular}

LNCaP

LNCaP-AR $+$

,+++ : The degree of gene expression in the cell line. ++ indicates more than 5 fold greater expression than $+(P<.01)$.

-: Very little amount was expressed. 
Table 2

Effect of PA, EA, POMx and PJ on gene expression of HSD3B2, AKR1C3, SRD5A1 and AR in LNCaP, LNCaP-AR and DU-145 prostate cancer cells

\begin{tabular}{|c|c|c|c|r|}
\hline Cell Line/Treatment & HSD3B2 & AKR1C & SRD5A1 & AR \\
\hline LNCaP & & & & \\
\hline PA & NS & ND & NS & NS \\
\hline EA & NS & ND & NS & NS \\
\hline POMx & $\downarrow$ & ND & NS & $\downarrow$ \\
\hline PJ & NS & ND & NS & NS \\
\hline LNCaP AR & & & & \\
\hline PA & $\downarrow$ & ND & $\downarrow$ & $\downarrow$ \\
\hline EA & $\downarrow$ & ND & $\downarrow$ & NS \\
\hline POMx & $\downarrow$ & ND & $\downarrow$ & $\downarrow$ \\
\hline PJ & & ND & $\downarrow$ & $\downarrow$ \\
\hline DU-145 & ND & NS & NS & ND \\
\hline PA & ND & $\downarrow$ & NS & ND \\
\hline EA & ND & NS & $\downarrow$ & ND \\
\hline POMx & ND & NS & NS & ND \\
\hline PJ & & & & \\
\hline Cell
\end{tabular}

Cells were incubated with punicalagin (PA $50 \mu \mathrm{g} / \mathrm{ml})$ ), ellagic acid (EA, $50 \mu \mathrm{g} / \mathrm{ml}$ ), pomegranate extract (POMx, $50 \mu \mathrm{g} / \mathrm{ml})$ or pomegranate juice (PJ, $100 \mu \mathrm{g} / \mathrm{ml}$ ) for 48 h. $n=4-6$. $\downarrow$ : More than two fold reduction at $P<.05$. NS: not significantly different compared to control $(0.1 \%$ DMSO) at $P<.05$. ND: Not detected indicates very low levels of gene expression in these cells. 